\title{
3 UNDERSTANDING THE DIFFUSION AND ADOPTION OF TELECOMMUNICATION INNOVATIONS: What We Know and What We Don't Know
}

\author{
Heidi Tscherning \\ Jan Damsgaard \\ Copenhagen Business School \\ Frederiksberg, Denmark
}

\begin{abstract}
This paper provides a systematic account about what we know and what we don't know about the diffusion and adoption of telecommunication innovations. As our sample, we obtained research papers from IFIP 8.6 conferences, the International Conference on Information Systems, and the European Conference on Information Systems from the past 10 years concerning telecommunication innovation diffusion and adoption to examine what aspects of the diffusion and adoption process are accentuated or overlooked using a general view of the process. As our theoretical vehicle, we build a holistic framework that comprises the innovation, the unit of adoption, and their interaction as captured by demand pull and supply push forces. The framework also takes into account the environment that embeds the diffusion and adoption. We find that there are certain shortcomings in the existing research within the field that need to be addressed to provide a more comprehensive view of adoption and diffusion of telecommunication technologies.
\end{abstract}

Keywords Telecommunication, innovation, diffusion, adoption

\section{INTRODUCTION}

The success of the mobile phone has been unprecedented; from being almost unknown 15 years ago, most people in the developed world now own one or more mobile

Please use the following format when citing this chapter:

Tscherning, H., and Damsgaard, J., 2008, in IFIP International Federation for Information Processing, Volume 287, Open IT-Based Innovation: Moving Towards Cooperative IT Transfer and Knowledge Diffusion, eds. León, G., Bernardos, A., Casar, J., Kautz, K., and DeGross, J. (Boston: Springer), pp. 39-60. 
phones. It has been embraced as the fourth technology carried by man - so in addition to the watch, the wallet, and the keys, we now also carry the mobile phone. Many people see the mobile phone as an extension of the self and in a sense we have become Cyborgs. ${ }^{1}$

The speed with which the mobile phone has spread has surprised most researchers. Today there are more than 3.3 billion mobile phone subscriptions in use in the world, ${ }^{2}$ growing at the astonishing rate of 200 million phones per quarter. It is not something that is limited to the Western world, as the mobile phone spread is pandemic. By 2011, it is estimated that nearly everyone on earth will own a mobile phone.

Even though the mobile phone has claimed global victory, not all telecommunication innovations are adopted with the same pursuit. That may not in itself be surprising but it has proven quite difficult to predict which innovations will succeed and which will fail. To illustrate, some telecommunication innovations such as short message service have previously exceeded expectations in terms of speed of adoption while others, for example multimedia messaging service, have not met expectations at all. The same holds true for global system for mobile, which has been tremendously successful in many parts of the world, whereas universal mobile telecommunications system has been much less so, even though it has gained momentum more recently.

Scholars of diffusion and adoption have also focused on telecommunication innovations and many different theories have been put to the test of explaining the phenomenon with varying results (Blechar et al. 2008). There seems to be no synthesis or dominant theory that captures all relevant aspects of the telecommunication diffusion process adequately. Indeed, some may argue, there may not be one best theory that will fit all our needs for understanding different aspects of the diffusion process. We agree to that point of view and just observe that at the moment we do not have a systematic account of the experiences of using different theories. In a respond to this deficit, this paper synthesizes what we know and, by exclusion, what we do not know about the diffusion and adoption of telecommunication innovations, as we believe that contributions to the selected conferences for the past 10 years cover most important findings in this area. As an analytical tool we develop a framework based on an overall model of diffusion and adoption of innovation. All articles published in proceedings from IFIP 8.6, the European Conference on Information Systems, and the International Conference on Information Systems over the past 10 years that portray the diffusion and adoption of telecommunication innovations are analyzed using the framework to provide an overall picture of the accounts. We realize that not all of the papers on this topic have been published in these outlets, but they provide a large and broad sample of available accounts. The aim is to condense knowledge that can help scholars better navigate between theories and their explanatory power vis-à-vis the research question they seek to remedy.

To achieve this objective, this paper is composed as follows: It begins with an overview of telecommunication innovations, and the remarkable success of mobile

\footnotetext{
${ }^{1}$ The definition of a Cyborg is a cybernetic organism, a hybrid of machine and organism (Haraway 1991).

${ }^{2}$ Reuters, "Global Cellphone Penetration Reaches 50 pct," November 29, 2007, http://investing.reuters.co.uk/news/articleinvesting. aspx?type=media\&storyID=nL29172095.
} 
phones is especially noted. The subsequent sections present our research method, our model of diffusion an adoption, and a generic analytical tool for investigating diffusion and adoption literature. The investigative tool is then applied to all relevant papers from IFIP 8.6, ECIS, and ICIS from the past 10 years and an analysis is conducted. Finally, our results are condensed and final conclusions are drawn.

\section{TELECOMMUNICATION INNOVATION}

Since its discovery, telecommunication has changed our lives in many ways, both privately and professionally. From a diffusion and adoption point of view, the first installations suffered from a lack of critical mass. If only a few people had access to a telephone, there where few people to call and hence the benefits of adopting a telephone were limited. However, as more people adopted the telephone, the benefits of joining the adopters also increased. This phenomenon, where one additional adopter increases the utility of the other adopters, is labeled network externalities (conomides and Salop 1992; Shapiro and Varian 1999) or network effects. Once the basic universal fixed-line telecommunication infrastructure was in place, many subsequent telecommunication innovations shared the accomplishments and have, therefore, not had to establish critical mass by themselves (i.e., subsequent telecommunications piggy-backed on the success of the fixed-line network).

This is, for example, the case of the mobile phone, which is always connected to the omnipresent fixed-line telecommunication infrastructure. The mobile phone represents an interesting case in that it is not only a device for voice communication but it has evolved into a data communication tool and also, increasingly, into a sophisticated computing device that can offer many different services. As an example, many mobile phones bundle cameras, FM radio-receivers, instant messengers, music players, and internet browsers. This means that the mobile device is not a fixed, single purpose innovation but a multifaceted and open-ended device. Its adoption is, therefore, not an atomic event but something that stretches over time and is quite learning intensive; the adopter will probably never use all of the possibilities that the mobile device can offer.

From a diffusion and adoption perspective, this complicates the matter. What is really the innovation being adopted? At what point in time should we denote the innovation as adopted? Finally, it is worth noticing that the mobile phone has to compete with other devices or communication channels that the potential adopter already uses. So at any given time, an adopter chooses between different available alternatives to satisfy her needs (Blechar et al. 2006) and any diffusion and adoption theory that seeks to understand and predict the faith of a telecommunication innovation has to consider not only the innovation at hand but also the alternatives. It is imperative here to consider established standards and habits as captured by switching costs and lock-in effects (Shapiro and Varian 1999).

Telecommunication innovations have always been subject to regulation (Melody 1999; Petrazzeni 1995). This holds true for the right to establish infrastructure and also the right to offer telecommunication services upon such infrastructure. Even though the period from the mid 1980s until now has been characterized as a period of deregulation, it is worth noting that deregulation has only been achieved through heavy use of regu- 
lation and legislation. For example, to increase the competition in the mobile telephony market, a number of licenses have been offered. The number and terms of the licenses are regulated by some telecommunication office. This means that a diffusion and adoption theory that seeks to offer broad and relevant explanations of the telecommunication innovation has to consider the context in which the process occurs.

\section{RESEARCH METHOD}

To recapture, the objective of this paper is to examine what aspects of the diffusion process are accentuated or overlooked in the diffusion and adoption process as reported in scholarly work and thereby condense knowledge that can help in the navigation between theories and their explanatory power. The overall research method applied is a literature study. In order to explore the aim of the paper, we use the following elements in a holistic framework to probe and analyze the articles: type of technology, adopting unit, interaction between the innovation and adopting unit expressed as supply-push or demand-pull mechanisms, as well as the context in which the diffusion and adoption occurs. Furthermore, we also explore the underlying theory and cause and effect structure of each paper.

\subsection{Data Collection}

The search for articles was conducted at the AIS website to locate ECIS and ICIS papers from the past 10 years, and the key words included diffusion, adoption, innovation, telecommunication, mobile (service), UTAUT, technology acceptance, actornetwork, network, institutional theory, critical mass, theory of reasoned action, and theory of planned behavior. The selection of these key words is based on the dominance they pose in diffusion and adoption research as well as the context in which this literature study is conducted. The search for IFIP 8.6 papers was conducted browsing through the last 10 years of proceedings identifying the same key words as for the ECIS and ICIS papers. Initially the combined search resulted in a total of 94 papers. However, after scanning the papers and eliminating those that were not specifically related to either a telecommunication technology or information and communication technologies in general that could include a telecommunication technology, we ended up with 36 papers.

Table 1. Number of Papers Investigated from the IFIP 8.6, ECIS, and ICIS Conferences, 1998-2007

\begin{tabular}{|l|c|c|c|c|c|c|c|c|c|c|}
\hline & $\mathbf{1 9 9 8}$ & $\mathbf{1 9 9 9}$ & $\mathbf{2 0 0 0}$ & $\mathbf{2 0 0 1}$ & $\mathbf{2 0 0 2}$ & $\mathbf{2 0 0 3}$ & $\mathbf{2 0 0 4}$ & $\mathbf{2 0 0 5}$ & $\mathbf{2 0 0 6}$ & $\mathbf{2 0 0 7}$ \\
\hline Conferences & 0 & $\mathrm{NC}$ & $\mathrm{NC}$ & 0 & 1 & 1 & 1 & 0 & 1 & 2 \\
\hline IFIP 8.6 & 0 & & & 0 & 1 & 1 & 1 & 0 & 1 & 2 \\
\hline ECIS & 0 & 0 & 0 & 0 & 4 & 2 & 4 & 7 & 3 & 3 \\
\hline ICIS & 0 & 1 & 0 & 1 & 1 & 1 & 1 & 1 & 1 & 0 \\
\hline
\end{tabular}


From IFIP 8.6, six papers (17 percent) were analyzed; from ECIS, we analyzed 23 papers (64 percent); from ICIS, seven papers (19 percent). No IFIP 8.6 conferences were held in the years 1999 and 2000, hence those years are marked as "NC" in the table (for an exhaustive IFIP 8.6 literature study see Henriksen and Kautz 2006).

\subsection{Data Analysis}

One of the authors read each paper carefully, making notes of sentences relating to the categories in our study framework. The analysis was an iterative process, and after this first categorization, the paper was reread if any category was still left empty in a search for clues to determine the right categorization.

Initially, the analysis was conducted searching for the main categories identified: type of innovation, adopting unit, interaction, and context, as well as a category for interesting observations. As the analysis progressed, it was clear that some of the categories were too broad and that is was necessary to perform a further division in some categories. It was, for example, of interest in the category "cause and effect structure" to determine how many papers investigated cause-effect or applied a process view and also whether the approach to the research was interpretive or positivistic.

Furthermore, it became clear as the analysis of an "interesting observations" category was analyzed that more categories were of interest for this analysis. An example is the "theory" categorization that seemed obvious as the papers analyzed are all papers of diffusion and adoption; however, the papers utilized both traditional diffusion and adoption theories as well as other theories.

\section{MODEL OF DIFFUSION AND ADOPTION}

Technology diffusion and adoption has been a key area of research in the Information Systems discipline since the influential work of (Davis 1989; Tornatzky and Klein 1982), and research has increased massively ever since.

Research has dealt with specific technologies such as the diffusion and adoption of electronic data interchange (Damsgaard and Lyytinen 1996; Lyytinen and Damsgaard 2001), Internet services (Pedersen and Ling 2003), and adoption of telecommunication services (Mahler and Rogers 1999). Researchers have also investigated such different perspectives as the level of adoption (Yoo et al. 2002), gender differences in individual technology adoption (Venkatesh et al. 2000), grouping of users into distinct profiles (Constantiou et al. 2007) and adoption of technologies in different geographical regions, for example, mobile services in German banks (Mahler and Rogers 1999) and South Korean broadband services (Yoo et al. 2002). Most papers apply one or more theoretical instrument developed for analyzing and predicting diffusion and adoption as it is recognized that technological advances and service availability do not automatically lead to widespread adoption and use (Constantiou et al. 2007). Based on previous research, a generic framework for investigation of technology diffusion and adoption is assembled. The framework is based on previous research and experience of one of the authors. 


\section{Context}

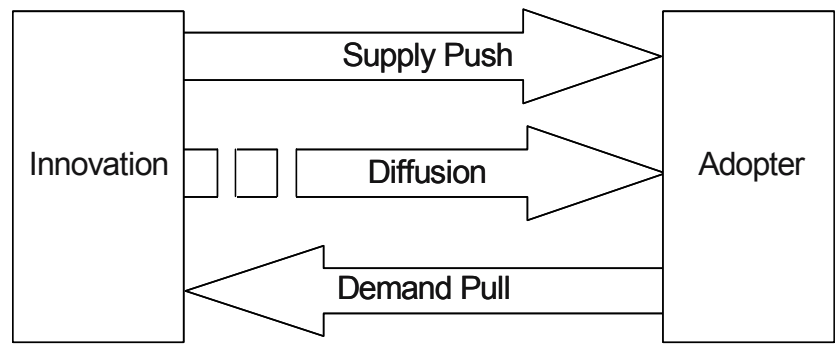

Figure 1. Holistic Framework for Investigating Technology Diffusion and Adoption (Static View)

Figure 1 shows a simple holistic framework for investigating technology diffusion and adoption of a snapshot in time. An innovation is diffused and adopted by one individual or a group of adopters as a consequence of a push from the producer or a pull from the adopters. This mechanism happens within a certain context; however, the framework shows a static view of this process and the changes that occur over a certain time period are not captured.

Often when an innovation is diffused and adopted by an adopting unit, the use of the innovation is further expanded. As the adopting unit identifies additional ways of using the innovation, or recognizes further needs in relation to the innovation, a demand pull mechanism takes place, and a transformation of the innovation transpires. This is depicted in Figure 2, which shows the process view of the holistic framework, where the innovation and the adopting unit are considered at times $\mathrm{T} 0$ and $\mathrm{T} 1$ to explore these changes.

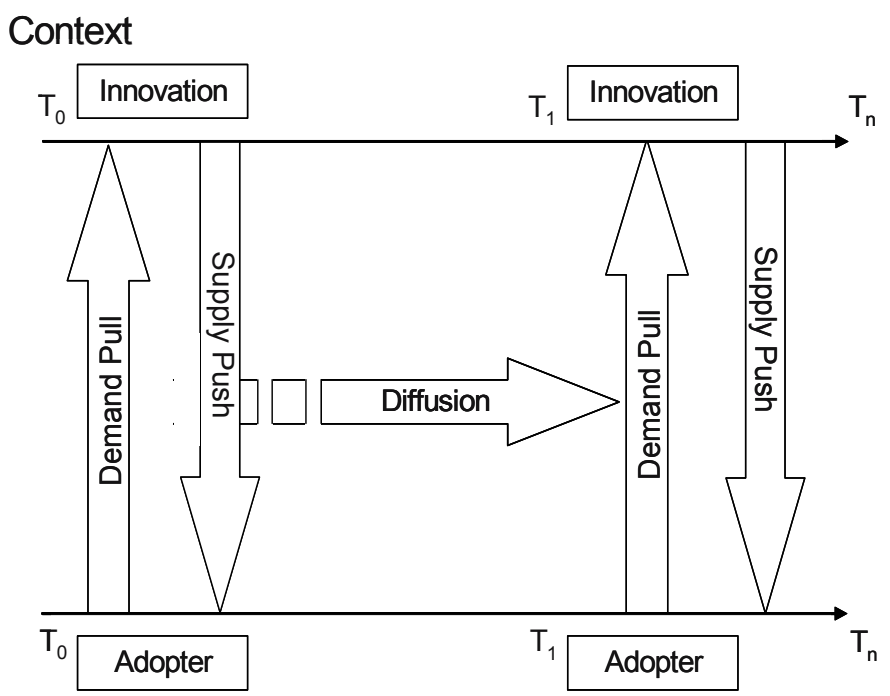

Figure 2. Holistic Framework for Investigating Technology Diffusion and Adoption (Process View) 
It is, therefore, of great interest to capture the distribution of articles that take a static view and a process view on the diffusion and adoption of telecommunication innovations.

Figures 1 and 2 provide an illustration of the diffusion process of innovations. They assist in understanding the elements and mechanisms of such a process. The elements of the framework are briefly introduced next.

\section{FRAMEWORK FOR ANALYZING DIFFUSION AND ADOPTION TELECOMMUNICATION LITERATURE}

\subsection{Type of Innovation}

Telecommunication technologies have developed extensively over the past decades and the massive increase of Internet users has led to dramatic shifts in the way business is conducted.

The type of innovation investigated in this paper can be labeled a telecommunication innovation as the telecommunication industry is in focus. As part of the type of innovation, there are certain traits of the innovation that are interesting to investigate as they affect the diffusion and adoption process. Some technologies are integrated in the work environment and are, therefore, compulsory whereas other technologies are adopted voluntarily. According to Moore and Benbasat (1991), this issue of compulsory versus voluntary adoption of a technology is of great significance. They define the voluntariness of use as "the degree to which use of the innovation is perceived as being voluntary or of free will" (p. 195). One can assume that when a technology is compulsory the adoption rate is either higher as a consequence of the innovation being forced upon the adopting unit, or the opposite - the adoption rate is lower as a consequence of the adopting unit's resistance to adopting a compulsory technology. Therefore, consideration must be given to whether individuals are free to implement personal adoption or rejection decisions when examining the diffusion and adoption.

As stated above, some technologies - especially networked technologies - enjoy network externalities. It is, moreover, interesting to investigate whether the innovation only has an inherent value for the individual user (private utility) or it only has value if most people in a community of practice use it (collective utility).

\subsection{Adopting Unit}

Researchers have for many years acknowledged that technologies affect organizations at different levels in different ways, and sought to understand associated behavioral phenomena (Banker and Kauffman 2004). We have adopted the classification develolped by Lyytinen and Yoo (2002), who analyzed the changes in demand in services and infrastructures at the individual, team, organizational, and interorganizational ${ }^{3}$ levels. Besides these four levels, when we found a paper studying the regional level, so we included that in our categorization.

${ }^{3}$ The interorganizational level is defined as adoption across the supply chain. 
The primary focus of IS research has been done with the individual (Carlsson et al. 2006; Venkatesh et al. 2000) and the organization (e.g., Mahler and Rogers 1999; Venkatesh and Davis 2007) as the focal points, and only little research has centered on the group level. In addition, group level analysis of diffusion and adoption of technologies has, in general, considered diffusion at an aggregate level of analysis of individuals instead of acknowledging that adoption of technologies at this level maintains synergy effects and, therefore, has different adoption curves.

In our analysis, we distinguish between the following levels of analysis: individual, group/team, organizational, interorganizational, and regional levels.

\subsection{Interaction Between Innovation and Adopting Unit}

Technology diffusion can furthermore be understood by using two additional means of explanations: supply-push and demand-pull theories (Damsgaard and Lyytinen 1996; Zmud 1984) that display the interaction between technologies and the adopting unit.

Supply-push theories assume that the functionality of a technology enables its diffusion. The innovation is being determined before it is pushed to the users and the push forces enclose the adoption decision as a rational choice problem between a former and a new technology. The main source of information to make this decision is different communication channels (Rogers 1995), notably mass media and peer networks; however, Lyytinen and Damsgaard (2001) reported that networked technologies can also be pushed "by powerful actors (gatekeepers) such as hubs, industry associations or government" (p. 9). Moreover, through sustained innovations within technologies, supply-side organizations try to make technologies more attractive for potential clients by encouraging users to acquire technologies as a technological problem-solver.

Demand-pull theories are conversely determined by the users' rational choice (Lyytinen and Damsgaard 2001; Rogers 1995). The demand-pull theories would explain the technology diffusion by a growing demand for technological solutions created by potential clients and their needs. Users' perceived usefulness and image is improved by applying scientific or technical knowledge. This creates the demand for innovations and triggers their adoption. This could, for example, be realized in the form of new technologies. The pull perspective predicts that innovators will choose to work on topics that are perceived as problems on the demand side (Thirtle and Ruttan 1987) and accordingly increase the probability of a technology being adopted and diffused by improving its fit to the personal or business needs of the adopting unit.

Although the diffusion of a technology cannot be explained either by the supplypush or the demand-pull forces alone, it is of interest to identify the force that drives the interaction between the technology and the adopting unit when studying diffusion and adoption.

\subsection{Context of Research}

In addition to the supply-push and demand-pull, it is also necessary to consider the context in which the diffusion and adoption of a technology takes place. The analysis of the context is mainly a macro analysis in which the diffusion and adoption of an inno- 
vation takes place and consists of entities such as national governments, international agencies, consumers, products and services, and other entities that might have an effect or the power to change the industries within the IS field (Damsgaard and Lyytinen 2001; King et al. 1994). Our analysis provides examples of the use of context in research but will not present data in tabular form as the context is characteristic for every single study.

\subsection{Theory}

The underlying theory of diffusion and adoption of an innovation revolves around different diffusion theories. The perception of diffusion and adoption was initially based on five classic characteristics of innovation derived by Rogers (1995) from diffusion of innovations (DOI) literature. The exploration of diffusion and adoption of technologies in the IS field furthermore includes other theories such as the technology acceptance model (TAM) (Davis 1989), the theory of reasoned action (TRA) (Ajzen and Fishbein 1980), theory of planned behavior (Ajzen 1985), as well as extensions to the above and the unified theory of acceptance and use of technology UTAUT) (Venkatesh et al. 2000). These theories have been widely used within the IS field; however, they are reported to show significant shortcomings in their ability to capture the diffusion and adoption of telecommunication services (Blechar et al. 2006).

Diffusion of innovations theory has had considerable impact on IS and has, therefore, been a widely used instrument to explain and predict rates of IT innovation diffusion (Moore and Benbasat 1991; Rogers 1995). It derives from rational theories of organizational existence and has its roots in economics, sociology, and communication theory and has attempted to explain mainly individual adoption decisions (Lyytinen and Damsgaard 2001).

TAM is one of the most widely accepted theories to explain and predict IS acceptance and facilitate design changes before users have experience with a system (Venkatesh et al. 2000; Venkatesh et al. 2003). TAM predicts user acceptance based on two specific behavioral beliefs: perceived ease of use (PEU) and perceived usefulness (PU), which determine an individual's behavior intention (BI) to use IT and subsequently actual use (Davis 1989). Several researchers have extended its use to different settings and succeeded in demonstrating reliability and validity of the instrument (Adams et al. 1992).

The theory of reasoned action (Ajzen and Fishbein 1974, 1980) is a model for the prediction of behavioral intentions and/or behavior. The theory has been useful for identifying where and how to target strategies for changing behavior. Later, Ajzen (1985) extended the boundary condition of pure volitional control in the model to incorporate perceived behavioral control as an antecedent to behavioral intentions in the theory of planned behavior by extending the theory of reasoned action.

UTAUT is an attempt by Venkatesh et al. (2003) at unifying eight renowned models of technology acceptance, diffusion and adoption: TRA, TAM, motivational model, TPB, combined TAM-TPB, model of PC utilization, diffusion of innovations theory, and social cognitive theory. The model is validated with six longitudinal field studies in usage intention and UTAUT is regarded as a superior model to the above models individually. However, only few studies apply this theory (Anderson and Schwager 2004).

The above theories within the field of diffusion and adoption of technologies are considered during the analysis; however, some papers include other theories in their 
analysis or do not include theories at all. This is taken into account in the analysis, where we examine the theories employed.

\subsection{Cause and Effect Structure}

Causality or causation captures the directional relationship between a cause and an effect. The effect is the outcome (result) of the cause. Often in diffusion and adoption models there is an aim to identify a set of predictor variables with a certain desirable outcome (adoption). There is often a distinction between necessary and sufficient causes of adoption. For example, TAM's constructs of perceived ease of use and perceived usefulness are both necessary and sufficient conditions for the intention to adopt. This type of theory, which explains why adoption occurs, is labeled variance theory (Markus and Robey 1988). Process theory, on the other hand, identifies a number of necessary conditions that, through a process, explain how the diffusion occurs.

\section{ANALYSIS AND DISCUSSION}

The initial data material consisted of 94 conference contributions; however, after an initial evaluation, the material was reduced to 36 conference contributions pertaining to diffusion and adoption of a telecommunication technology.

The analysis is conducted by analyzing the conference contributions according to the six elements described above. The analysis is structured in the following way: each element is discussed in relation to the framework described above. For an overview, the discussion paragraph also contains a table showing the number of contributions within each element. The papers are referenced through a unique ID (from 1 to 36) associated with each contribution. The appendix shows a table linking each ID with a paper contribution and the elements of the framework. The analysis draws upon findings that show both findings that are representative to the articles and findings that are peculiar. The results are represented in percentages and are discussed, although the sample is relatively small, as percentages act as a visualization of the results.

\subsection{Type of Innovation}

All papers investigated studied a specific telecommunication technology or the more general concept of ICT. The ICT papers selected for this literature study all analyzed ICT that could irrefutably include a telecommunication technology. The majority of the papers (94 percent) deal directly with telecommunication technologies and innovations and only 6 percent of the papers concern ICT. Although several researchers have classified types of technologies, no classification has been provided within ICT or telecommunication technologies. It is, however, apparent that the majority of the papers ( 72 percent) analyze the diffusion and adoption of mobile devices and services such as mobile TV services (Lin and Chiasson 2007), mobile devices and services (Constantiou et al. 2005), and video streaming (Stanoevska-Slabeva and Hoegg 2005), whereas only 
22 percent analyze the diffusion and adoption of broadband technologies (e.g., Choudrie and Dwivedi 2005; Damsgaard and Gao 2004). A few papers include a study of both; for example, a solution containing a combination of GPRS phone, PC, and WLAN (Breu et al. 2005) and broadband and mobile services (Middleton 2002).

Looking at the division of papers investigating the diffusion and adoption of compulsory and voluntary use of technologies, it is worth noticing that the papers contain an overweight of voluntary use ( 81 percent of the papers) of technologies. This is expected as these technologies are widely used in personal settings where users adopt a technology voluntarily. There is a clear correlation between voluntary use of a technology and the level of adoption analyzed (i.e., 67 percent of the papers investigating technologies adopted voluntarily were adopted at the individual level). However, at the organizational, group, and regional levels, 19 percent $^{4}$ of the papers were related to compulsory use and 14 percent $^{5}$ were related to voluntary diffusion and adoption of technologies.

There is a slight overweight of papers investigating compulsory use of technologies in organizations. Muzzi and Kautz (2004) investigated adoption of ICT through two studies and found that firms that involve high investments and a clear projection, such as ERP, videoconferences, EDI, and groupware have not been widely adopted. Most of these are technologies enforced upon employees in an organization and further research could, therefore, benefit from the investigation of compulsory use of ICT to explain this lack of adoption. As noted before, the adoption rate of a compulsory technology can be higher or lower as a consequence the adopting unit's resistance to adopting the enforced technology.

Of the papers analyzed, 17 percent are directly concerned with technologies that enjoy network externalities and 83 percent are not. However, it cannot be deduced that the technologies do not benefit from these; it is just not apparent in the papers.

Table 2. Papers Distributed on the Compulsory and Voluntary Use of Technologies

\begin{tabular}{|c|c|c|c|c|c|c|}
\hline & $\begin{array}{c}\text { \# of } \\
\text { papers }\end{array}$ & IFIP 8.6 & $\begin{array}{c}\text { \# of } \\
\text { papers }\end{array}$ & ECIS & $\begin{array}{c}\text { \# of } \\
\text { papers }\end{array}$ & ICIS \\
\hline Compulsory & 2 & 4,5 & 3 & $10,22,23$ & 2 & 32,36 \\
\hline Voluntary & 4 & $1,2,3,6$ & 20 & $\begin{array}{l}7,8,9,11,12,13, \\
14,15,16,17,18, \\
19,20,21,24,25, \\
26,27,28,29\end{array}$ & 5 & $\begin{array}{l}30,31,33, \\
34,35\end{array}$ \\
\hline $\begin{array}{l}\text { With network } \\
\text { effects }\end{array}$ & 2 & 2,4 & 1 & 11 & 3 & $30,34,36$ \\
\hline $\begin{array}{l}\text { Without } \\
\text { network } \\
\text { effects }\end{array}$ & 4 & $1,3,5,6$ & 22 & $\begin{array}{l}7,8,9,10,12,13, \\
14,15,16,17,18, \\
19,20,21,22,23, \\
24,25,26,27,28, \\
29\end{array}$ & 4 & $\begin{array}{l}31,32,33, \\
35\end{array}$ \\
\hline
\end{tabular}

${ }^{4}$ Compulsory use: organizational level: $14 \%$; group level: $2.5 \%$; regional level: $2.5 \%$.

${ }^{5}$ Organizational level: $14 \%$. 
Table 3. Papers Distributed on Adopting Unit of Technologies

\begin{tabular}{|c|c|c|c|c|c|c|}
\hline & $\begin{array}{c}\text { \# of } \\
\text { papers }\end{array}$ & IFIP 8.6 & $\begin{array}{c}\text { \# of } \\
\text { papers }\end{array}$ & ECIS & $\begin{array}{c}\text { \# of } \\
\text { papers }\end{array}$ & ICIS \\
\hline Individual & 3 & $1,2,6$ & 17 & $\begin{array}{l}7,8,9,11,12,15 \\
16,17,18,19,20 \\
21,25,26,27,28 \\
29\end{array}$ & 5 & $\begin{array}{l}30,31, \\
33,34 \\
35\end{array}$ \\
\hline Group/team & 0 & - & 0 & - & 1 & 36 \\
\hline Organizational & 2 & 3,4 & 6 & $\begin{array}{l}10,13,14,22,23, \\
24\end{array}$ & 1 & 32 \\
\hline Interorganizational & 0 & - & 0 & - & 0 & - \\
\hline Regional & 1 & 5 & 0 & - & 0 & - \\
\hline
\end{tabular}

\subsection{Adopting Unit}

Approximately 69 percent of the research conducted in the past 10 years represents the individual level. This is not surprising as mobile services and technologies are often targeted to individuals and their needs. The units of adoption investigated are distributed in the papers as follows: individuals: 25 (69 percent); groups/teams 1 ( 3 percent); organizations: 9 (25 percent); interorganizational: 0 ( 0 percent); regions: 1 (3 percent). It is interesting to note that research at the interorganizational level is not represented at all.

The distribution of papers from the three investigated conferences is representative for research of the different adopting units within the IS field as such.

Diffusion and adoption of technologies in social networks have been discussed lately; however, only one paper out of 36 discusses adoption at the group level of analysis (Harrington and Ruppel 1999). They discuss practical and value compatibility and its relationship to telecommuting's adoption, diffusion, and success among IS personnel. The study is conducted in an organizational setting but the authors study group values, and, therefore, the paper has been classified as research at the group level. It should be mentioned that Sarker (2006) examined the levels of analysis issue in understanding technology adoption by groups. Sarker points out that groups should be investigated and "treated in their own right," and not as an aggregation of the individuals (pp. 1276). We concur with this point of view.

It can be argued that in the future researchers should conduct studies at the group level and within organizations. When investigating organizations, researchers should bear in mind that the internal structure of many organizations consists of working groups and teams with their own and not just a large number of individuals.

\subsection{Context of Research}

The context in which the research in the investigated studies takes place is of great importance to the research question posed. Most of the papers performing empirical data collection describe the context in which the study is performed with a fair amount of 
detail. When conducting research in the telecommunication industry, it is necessary to capture local regulations and policies for the markets investigated as these may have considerable impact in explaining the adoption and diffusion of a telecommunication innovation. Constantiou and Papazafeiropoulou (2006) explain the Danish market in detail when they investigate the provider's perspective in IP-telephony diffusion. Oh and Lee (2005) explain how alliances between mobile carriers, banks, and other related parties are formed, and analyze how technology affects competition and collaboration among them when a new convergence service is created by two, previously unrelated, industries - banks and mobile carriers - as mobile carriers had a hidden agenda to enter the financial market. This information provides a deeper understanding of the market and thereby the adoption and diffusion.

\subsection{Theory}

It is common for researchers to use an analytical framework in the analysis of diffusion and adoption studies. Rogers' (1995) diffusion of innovations is one of the often applied theories in numerous fields of study, but researchers have come to understand that other frameworks and theories might explain the diffusion and adoption of telecommunication technologies even better. There are still some gaps in the application of certain theoretical frameworks, and it is apparent from Table 4 that both the TRA and TPB, or even more interesting the UTAUT, are totally absent in the research conducted in this field of research the past ten years in contributions submitted to the three investigated conferences.

TAM is still the most applied theory in the field even though the application of the theory in this study seems moderate. In all, 19 percent of the papers analyze technology acceptance using this theory. TAM has been widely criticized for not being falsifiable, its questionable heuristic value, and its limited explanatory and predictive power (e.g., Szajna 1994). This could be the reason for the relatively diminished application. Researchers have attempted to explain (the lack of) diffusion and adoption of technologies using a variety of other theories relevant to the context they are investigating;

Table 4. Papers Employing the Most Applied Theories of Diffusion and Adoption

\begin{tabular}{|c|c|c|c|c|c|c|}
\hline & $\begin{array}{c}\text { \# of } \\
\text { papers }\end{array}$ & IFIP 8.6 & $\begin{array}{c}\text { \# of } \\
\text { papers }\end{array}$ & ECIS & \begin{tabular}{|c|}
$\begin{array}{c}\text { \# of } \\
\text { papers }\end{array}$ \\
\end{tabular} & ICIS \\
\hline DOI & 2 & 1,3 & 1 & 20 & 1 & 36 \\
\hline TAM/TRA & 0 & - & 7 & $\begin{array}{l}10,13,15,19,23 \\
25,27\end{array}$ & 0 & - \\
\hline TPB & 0 & - & 0 & - & 0 & - \\
\hline UTAUT & 0 & - & 0 & - & 0 & - \\
\hline Other & 3 & $4,6,7$ & 10 & $\begin{array}{l}7,9,12,17,18, \\
21,22,24,26,29\end{array}$ & 5 & $\begin{array}{l}30,31,32, \\
33,34,35\end{array}$ \\
\hline None & 2 & 2,5 & 5 & $8,11,14,16,28$ & 0 & - \\
\hline
\end{tabular}


for example, Walden et al. (2007) apply the Braudel rule as a theoretical framework to find out why and how mobile services can make sense as a basis for viable business. They paraphrased the Braudel rule by stating that "mobile services become mobile value services when they offer the possibility to expand the limits of the possible in the structure of everyday routines" (p. 1876). They found that the mobile services investigated did not satisfy the Braudel rule.

Haghirian and Madlberger (2005) use advertising theory to analyze the consumer attitude toward advertising via mobile devices in Austria, and Cheng and Arthur (2002) propose using the trans-theoretical model of behavior change to explain the construction of a mobile internet healthcare solution for problem drinkers. Several papers choose not to apply a theoretical framework to their studies but instead conduct empirical data collection and analyze the results statistically (e.g., Abu-Samaha and Mansi 2007).

Dahlberg and Mallat (2002) use consumer perceived value (Grönroos 1997), technology acceptance model, and network externalities theory to explain managerial implications of consumer value perceptions in relation to mobile payment service development. The usage of the three theories is an attempt to impede the shortcomings of each theory individually. This implies a need for testing and evaluating more theories within the field of diffusion and adoption of telecommunication innovations to explain the observable facts.

\subsection{Cause and Effect Structure}

Of the papers investigated, 83 percent depict the relationship between a cause and an effect and only 17 percent take a process view and seek to explain how diffusion and adoption occur over time. Most research within telecommunication theory takes a static view when investigating diffusion and adoption of technologies and thereby does not take that into account when an innovation is adopted and diffused by an adopting unit, the use of the innovation is further expanded, and a transformation of the technology takes place. Wareham et al. (2002) is an example of a paper that tries to accommodate this shortcoming in research as they gather data in two stages to investigate the implications for

Table 5. Papers Depicting Cause-Effect or Process View and Research Approach

\begin{tabular}{|c|c|c|c|c|c|c|}
\hline & $\begin{array}{c}\text { \# of } \\
\text { papers }\end{array}$ & IFIP 8.6 & $\begin{array}{c}\text { \# of } \\
\text { papers }\end{array}$ & ECIS & $\begin{array}{c}\text { \# of } \\
\text { papers }\end{array}$ & ICIS \\
\hline Cause-effect & 5 & $\begin{array}{l}1,2,3,4, \\
6\end{array}$ & 19 & $\begin{array}{l}7,8,10,11,12,13, \\
14,15,16,17,19 \\
20,21,23,24,25, \\
26,27,28\end{array}$ & 6 & $\begin{array}{l}31,32,33 \\
34,35,36\end{array}$ \\
\hline Process & 1 & 5 & 4 & $9,18,22,29$ & 1 & 30 \\
\hline $\begin{array}{l}\text { Interpretive } \\
\text { approach }\end{array}$ & 5 & $\begin{array}{l}1,3,4,5, \\
6\end{array}$ & 9 & $\begin{array}{l}10,11,13,20,21, \\
22,24,27,28\end{array}$ & 4 & $\begin{array}{l}30,31,32, \\
34\end{array}$ \\
\hline $\begin{array}{l}\text { Positivistic } \\
\text { approach }\end{array}$ & 1 & 2 & 14 & $\begin{array}{l}7,8,9,12,14,15 \\
16,17,18,19,23 \\
25,26,29\end{array}$ & 3 & $33,35,36$ \\
\hline
\end{tabular}


the digital divide in wireless diffusion and mobile computing. The first sample of survey data was obtained in 1994 and contains information from 8,700 households, and the second sample was gathered in 1998 and contains over 16,000 households. Their results should be used to predict how mobile telecom diffusion may affect the digital divide as Internet access is incorporated by smartphones and wireless.

Studies taking a process view provide a dynamic and thereby more realistic view on the diffusion process, and therefore more studies should be conducted to offer further insight.

A slight majority of the studies within the field take a positivistic approach -56 percent - but the distribution of interpretive versus positivistic papers are fairly even.

\section{CONCLUSION}

This paper has provided a framework for analyzing what we know and what we don't know about the diffusion and adoption of telecommunication innovations and provided insight into what aspects of the diffusion and adoption process are accentuated or overlooked using a general view of the process. Three conferences have been chosen in this analysis, as the coverage at these conferences spans IS research to a wide extent. Many important contributions have been accepted in a variety of journals and we do not claim that this literature study is comprehensive; however, we believe that the elements within the diffusion and adoption framework are covered at these conferences.

Through our holistic framework, we found that most research has been conducted on the voluntary use of technologies targeting the individual. There is nearly a total absence of papers investigating the group and the interorganizational level of adoption. As social networks have gained attention in the past 10 years, this is surprising and it is therefore recommended that further research into this level of adoption be performed.

Many different theories and frameworks are used to explain the adoption and diffusion of innovations, and TAM is used frequently. It seems that researchers apply theories not only linked to adoption and diffusion to investigate further explanations to the research problem in question but also theories from other fields of study and this trend is encouraging as there is no dominant theory that captures all relevant aspects of the telecommunication diffusion process adequately. Theories that look into the network externalities from which the telecommunication technologies benefit are especially interesting when seeking explanations for diffusion and adoption.

Most studies take a cause-effect view in a snapshot in time and not a process view that could provide a dynamic and thereby more realistic view on the diffusion process and therefore more studies should be conducted to offer further insight. The distribution of interpretive versus positivistic approaches to the studies is equal and this trend should continue.

Finally, it is worth mentioning that the emerging field of neuroeconomics might complement diffusion and adoption research within information systems. Neuroeconomics seeks to develop our understanding of human behavior and, in particular, the role of emotions and emotional response (Damasio 1994; Hansen and Christensen 2007; Seo and Barett 2007). As TAM has recently been criticized for redirecting researchers' attention away from the antecedents of beliefs, not taking the IT artifact or its design into account, neglecting important outcomes of information technology (Benbasat and Barki 
2007), as well as reaching maturity (Venkatesh et al. 2007), Dimoka et al. (2007) have proposed the application of neuro-science theories, methods, and tools to the field and labeled it neuro-IS. The field might benefit from the exploration and exploitation of cognitive neuroscience to improve and advance information systems.

This paper contributes with an overview of the existing research within diffusion and adoption of telecommunications research and provides a suggestion for areas in which further research is needed: research is needed at the group level, continual research applying different theoretical views than the widely used DOI and technology acceptance theories (e.g., theories from the field of neuroeconomics) may capture new aspects of the telecommunication diffusion process, and finally research taking a process view.

\section{References}

Abu-Samaha, A. M., and Mansi, I. 2007. "Information Technology Diffusion in the Jordanian Telecom Industry," in Organizational Dynamics of Technology-Based Innovation: Diversifying the Research Agenda, T. McMaster, D. Wastell, E. Ferneley, and J. I. DeGross (eds.), Boston: Springer, pp. 431-442.

Adams, D. A., Nelson, R. R., and Todd, P. A. 1992. "Perceived Usefulness, Ease of Use, and Usage of Information Technology: A Replication," MIS Quarterly (16:2), pp. 227-247.

Ajzen, I. 1985. "From Intentions to Actions: A Theory of Planned Behavior," in Action-Control: From Cognition to Behavior, J. Kuhl and J. Beckman (eds.), New York: Springer-Verlag, pp. 11-39.

Ajzen, I., and Fishbein, M. 1974. "Factors Influencing Intentions and Intention-Behavior Relation," Human Relations (27:1), pp. 1-15.

Ajzen, I., and Fishbein, M. 1980. Understanding Attitudes and Predicting Social Behavior, Englewood Cliffs, NJ: Prentice-Hall.

Anderson, J. E., and Schwager, P. H. 2004. "SME Adoption of the Wireless LAN Technology: Applying the UTAUT Model," in Proceedings of the $7^{\text {th }}$ Annual Conference of the Southern Association for Information Systems, Savannah, GA, February 27-28, pp. $39-43$ (http://sais. aisnet.org/2004/Anderson\%20\&\%20Schwager.pdf).

Banderker, N., and Van Belle, J.-P. 2006. "Mobile Technology Adoption by Doctors in Public Healthcare in South Africa," in Proceedings of the $14^{\text {th }}$ European Conference on Information Systems, J. Ljunberg and M. Andersson (eds.), Gothenburg, Sweden, June 12-14, pp. 1-13 (http://www.commerce.uct.ac.za/InformationSystems/Research\&Publications/2006/ ECIS06\%20223\%20Mobile\%20Techn\%20in\%20Healthcare.pdf).

Banker, R. D., and Kauffman, R. J. 2004. "The Evolution of Research on Information Systems: A Fiftieth-year Survey of the Literature in Management Science," Management Science (50:3), pp. 281-298.

Benbasat, I., and Barki, H. 2007. Quo Vadis, Tam?," Journal of the AIS, (8:4), pp. 211-218.

Blechar, J., Constantiou, I. D., and Damsgaard, J. 2006. "Exploring the Influence of Reference Situations and Reference Pricing on Mobile Service User Behavior," European Journal of Information Systems (15:3), pp. 285-291.

Breu, K., Hemingway, C., and Ashurst, C. 2005. "The Impact of Mobile and Wireless Technology on Knowledge Workers: An Exploratory Study," in Proceedings of the $13^{\text {th }}$ European Conference on Information Systems, Regensburg, Germany, May 26-28, pp. 1-12 (http:// aisel.aisnet.org/Publications/ECIS/2005/20050098.pdf).

Carlsson, C., Carlsson, J, Hyvönen, K., Puhakainen, J., and Walden, P. 2006. "Adoption of Mobile Devices/Services - Searching for Answers with the UTAUT," in Proceedings of the $39^{\text {th }}$ Hawaii International Conference on System Sciences, Los Alamitos, CA: IEEE Computer Society Press, pp. 132-142. 
Carlsson, C., Carlsson, J., and Walden, P. 2005. "Mobile Services for the Hospitality Industry," in Proceedings of the $13^{\text {th }}$ European Conference on Information Systems, Regensburg, Germany, May 26-28.

Cheng, E., and Arthur, D. 2002. "Constructing a Virtual Behavior Change Support System: A Mobile Internet Healthcare Solution for Problem Drinkers," in Proceedings of the $10^{\text {th }}$ European Conference on Information Systems, Gdansk, Poland, June 6-8 (http://is2.lse.ac.uk/ asp/aspecis/20020030.pdf).

Choudrie, J., and Dwivedi, Y. 2005. "Investigating Broadband Diffusion in the Household: Towards Content Validity and Pre-Test of the Survey Instrument," in Proceedings of the $13^{\text {th }}$ European Conference on Information Systems, Regensburg, Germany, May 26-28 (http:// aisel.aisnet.org/Publications/ECIS/2005/20050044.pdf)..

Choudrie, J., Papazafeiropoulou, A., and Lee, H. 2003. "Applying Stakeholder Theory to Analyze the Diffusion of Broadband in South Korea: The Importance of the Government's Role," in Proceedings of the $11^{\text {th }}$ European Conference on Information Systems, Napoli, Italy, June 15-21 (http://is2.lse.ac.uk/asp/aspecis/20030031.pdf).

Constantiou, I. D., Damsgaard, J., and Knutsen, L. 2007. "The Four Incremental Steps toward Advanced Mobile Service Adoption," Communications of the ACM (50:6), pp. 51-55.

Constantiou, I. D., Damsgaard , J., and Knutsen, L. 2005. "Beware of Dane-geld: Even if Paid, M-Service Adoption Can be Slow," in Proceedings of the $13^{\text {th }}$ European Conference on Information Systems, Regensburg, Germany, May 26-28.

Constantiou, I., and Papazafeiropoulou, A. 2006. " The Providers' Perspective in IP-Telephony Diffusion: Insights from the Danish Market," in Proceedings of the $14^{\text {th }}$ European Conference on Information Systems, J. Ljunberg and M. Andersson (eds.), Gothenburg, Sweden, June 12-14, pp. 608-617.

Coursaris, C., Hassanein, K., Head, M., and Bontis, N. 2007. "The Impact of Distractions on the Usability and the Adoption of Mobile Devices for Wireless Data Services," in Proceedings of the $15^{\text {th }}$ European Conference on Information Systems, St. Gallen, Switzerland, June 7-9.

Dahlberg, T., and Mallat, N. 2002. "Mobile Payment Service Development-Managerial Implications of Consumer Value Perceptions," in Proceedings of the $10^{\text {th }}$ European Conference on Information Systems, Gdansk, Poland, June 6-8, pp. 649-657 (http://is2.lse.ac.uk/ asp/aspecis/20020144.pdf)

Damasio, A. R. 1994. Descartes' Error: Emotion, Reason, and the Human Brain, New York: G. P. Putnam.

Damsgaard, J., and Gao, P. 2004. "Mobile Telecommunications Market Innovation: The Transformation from 2G to 3G," in Proceedings of the $12^{\text {th }}$ European Conference on Information Systems, T. Leino, T. Saarinen, and S. Klein, Turku, Finland, June 14-16 (http://is2.lse.ac.uk/ asp/aspecis/20040038.pdf).

Damsgaard, J., and Lyytinen, K. 1996. "Government Strategies to Promote the Diffusion of Electronic Data Interchange (EDI): What We Know and What We Don't Know," Information Infrastructure and Policy (5:3), pp. 169-191.

Damsgaard, J., and Lyytinen, K. 2001. "The Role of Intermediating Institutions in Diffusion of Electronic Data Interchange (EDI): How Industry Associations in the Grocery Sector Intervened in Hong Kong, Finland, and Denmark," The Information Society (17:3), pp. 195-210.

Davis, F. D. 1989. "Perceived Usefulness, Perceived Ease of Use, and User Acceptance of Information Technology," MIS Quarterly (13:3), pp. 319-340.

Dimoka, A., Pavlou, P. A., and Davis, F. D. 2007. "Neuro-IS: The Potential of Cognitive Neuoscience for Information Systems Research," in Proceedings of the $28^{\text {th }}$ International Conference on Information Systems, Montreal, Canada, December 9-12 (http:// www. agsm.ucr. edu/faculty/staff/pavlou/ICIS_Dimoka_Pavlou_Davis_2007.pdf).

Dutta, A., and Roy, R. 2001. "The Mechanics of Internet Diffusion in India: Lessons for Developing Countries," in Proceedings of the $22^{\text {nd }}$ International Conference on Information Systems, V. Storey, S. Sarkar, and J. I. DeGross (eds.), New Orleans, December 16-19, pp. 587-592. 
Dwivedi, Y. K., Choudrie, J., and Weerakkody, V. 2006. "Broadband Adoption in the UK Household: Towards Reliability and Construct Validity of a Survey Instrument," in Proceedings of the $14^{\text {th }}$ European Conference on Information Systems, J. Ljunberg and M. Andersson (eds.), Gothenburg, Sweden, June 12-14.

Economides, N., and Salop, S. C. 1992. "Competition and Integration among Complements, and Network Market-Structure," Journal of Industrial Economics (40:1), pp. 105-123.

Goh, K.-Y., Lee, C and Lee, C. 2003. "Information Technology Product Bundling in the Prescence of Complementarities, Quality Uncertainty and Network Effects: An Agent-Based Approach," in Proceedings of the $24^{\text {th }}$ International Conference on Information Systems, S. T. March. A. Massey, and J. I. DeGross (eds.), Seattle, WA, December 14-17, pp. 497-510.

Grönroos, C. 1997. "Value-Driven Relational Marketing: From Products to Resources and Competences," Journal of Marketing Management (13:5), pp. 407-439.

Haghirian, P., and Madlberger, M. 2005. "Consumer Attitude Toward Advertising via Mobile Devices-An Empirical Investigation Among Austrian Users," in Proceedings of the $13^{\text {th }}$ European Conference on Information Systems, Gdansk, Poland, June 6-8 (http://is2.lse.ac.uk/ asp/aspecis/20050038.pdf).

Hampe, F., and G. Schwabe (2002). "Enhancing Mobile Commerce: Instant Music Purchasing over the Air," in Seeking Success in E-Business: A Multidisciplinary Approach, K. V. Andersen, S. Elliot, P. Swatman, E. Trauth, and J. Bjørn-Andersen (eds.), Norwell, MA: Kluwer Academic Publishers, pp. 107-131.

Hansen, F., and Christensen, S. R. 2007. Emotions, Advertising and Consumer Choice, Copenhagen: Copenhagen Business School Press.

Haraway, D. 1991. "A Cyborg Manifesto: Science, Technology, and Socialist-Feminism in the Late Twentieth Century," Simians, Cyborgs and Women: The Reinvention of Nature, New York: Routledge, pp. 149-181.

Harrington, S., and Ruppel, C. 1999. "Practical and Value Compatibility: Their Roles in the Adoption, Diffusion and Success of Telecommuting," in Proceedings of the $19^{\text {th }}$ International Conference on Information Systems, P. De and J. I. DeGross (eds.), Charlotte, NC, December 13-15, pp. 103-112.

Henriksen, H. Z., and Kautz, K. 2006. "An Analysis of IFIP TC 8 WG 8.6 - In Search of a Common Theoretical Denominator," in The Past and Future of Information Systems: 1976-2006 and Beyond, IFIP World Computer Congress, TC8, Information Systems Stream, Santiago, Chile, August 21-23, pp. 143-152.

King, J. L., Gurbaxani, V., Kraemer, K. L., McFarlan, F. W., Raman, K. S., and Yap, C. S. 1994. "Institutional Factors in Information Technology Innovation," Information Systems Research (5:2), pp. 139-169.

Knebel, U., Leimeister, J. M., and Krcmar, H. 2007. "Personal Mobile Sports Companion: Design and Evaluation of IT-Supported Product-Service Bundles in the Sports Industry," in Proceedings of the $15^{\text {th }}$ European Conference on Information Systems, St. Gallen, Switzerland, June 7-9.

Leimeister, J.-M., Daum, M., and Krcmar, H. 2002. "Mobile Virtual Healthcare Communities: An Approach to Community Engineering for Cancer Patients," in Proceedings of the $10^{\text {th }}$ European Conference on Information Systems, Gdansk, Poland, June 6-8, pp. 1626-1637 (http://is2.lse.ac.uk/asp/aspecis/20050038.pdf).

Lin, S., and Chiasson, M. W. 2007. "A Dynamic Approach to Context Diffusion Research: An Actor-Network Theory Study of Mobile TV Service," in Organizational Dynamics of Technology-Based Innovation: Diversifying the Research Agenda, T. McMaster, D. Wastell, E. Ferneley, and J. I. DeGross (eds.), Boston: Springer, pp. 315-330.

Lyytinen, K., and Damsgaard, J. 2001. "What's Wrong with Diffusion of Innovations Theory?," in Proceedings of the IFIP TC8/WG 8.1. Fourth Working Conference on Diffusing Software Products and Process Innovations, M. A. Ardis and B. L. Marcolin (eds.), Deventer, The Netherlands: Kluwer B.V., pp. 173-190.

Lyytinen, K., and Yoo, Y. 2002. "Research Commentary: The Next Wave of Nomadic Computing," Information Systems Research (13:4), pp. 377-389. 
Mahler, A., and Rogers, E. M. 1999. "The Diffusion of Interactive Communication Innovations and the Critical Mass - The Adoption of Telecommunications Services by German Banks," Telecommunications Policy (23), pp. 719-740.

Markus, M. L., and Robey, D. 1988. "Information Technology and Organizational Change: Causal Structure in Theory and Research," Management Science (34:5), pp. 583-598

McManus, P., and Standing, C. 2004. "The Value of Life Histories in Researching the Adoption and Use of M-Services," in Proceedings of the $12^{\text {th }}$ European Conference on Information Systems, T. Leino, T. Saarinen, and S. Klein (eds.), Turku, Finland, June 14-16 (http:// is2.lse.ac.uk/asp/aspecis/20040107.pdf).

Melody, W. H. 1999. "Telecom Reform: Progress and Prospects," Telecommunications Policy (23:1), pp. 7-34.

Middleton, C. 2002. "Exploring Consumer Demand for Networked Services: The Importance of Content, Connectivity and Killer Apps in the Diffusion of Broadband and Mobile Services," in Proceedings of the $23^{\text {rd }}$ International Conference on Information Systems, L. Applegate, R. Galliers, and J. I. DeGross (eds.), Barcelona, Spain, December 15-18, pp. 391-399.

Moore, G. C., and Benbasat, I. 1991. "Development of an Instrument to Measure the Perceptions of Adopting an Information Technology Innovation," Information Systems Research (2:3), pp. 192-222.

Muzzi, C., and Kautz, K. 2004. "Information and Communication Technologies Diffusion in Industrial Districts," in Networked Information Technologies: Diffusion and Adoption, J. Damsgaard and H. Z. Henriksen (eds.), Norwell, MA: Kluwer Academic Publishers, pp. 19-39.

Ney, M., Schätz, B., Höck, J., and Salzmann, C. 2004. "Introducing Mobility: The mPolice Project," in IT Innovation for Adaptability and Competitiveness, B. Fitzgerald and E. Wynn (eds.), pp. 383-405.

Oh, S., and Lee, H. 2005. "How Technology Shapes the Actor-Network of Convergence Services: a Case of Mobile Banking," in Proceedings of the $26^{\text {th }}$ International Conference on Information Systems, D. Avison, D. Galletta, and J. I. DeGross (eds.), Las Vegas, NV, December 11-14, pp. 483-493.

Pedersen, P., and Ling, R. 2003. "Modifying Adoption Research for Mobile Internet Service Adoption Crossdisciplinary," in Proceedings of the $36^{\text {th }}$ Hawaii International Conference on System Sciences, Los Alamitos, CA: IEEE Computer Society Press.

Petrazzeni, B. A. 1995. The Political Economy of Telecommunications Reform in Developing Countries: Privatization and Liberalization in Comparative Perspective, Westport, CT: Praeger Publishers.

Rogers, E. M. 1995. Diffusion of Innovations, New York: Free Press.

Sarker, S. 2006. "Examining the 'Level of Analysis" Issue in Understanding Technology Adoption by Groups: Social, Behavioral, and Organizational Aspects of Information Systems," in Proceedings of the $27^{\text {th }}$ International Conference on Information Systems, Milwaukee, WI, December 10-13, pp. 1275-1286.

Scheepers, H., and McKay, J. 2004. An Empirical Assessment of the Business Value Derived from Implementing Mobile Technology. A Case Study of Two Organizations," in Proceedings of the $12^{\text {th }}$ European Conference on Information Systems, T. Leino, T. Saarinen, and S. Klein (eds.), Turku, Finland, June 14-16 (http://is2.lse.ac.uk/asp/aspecis/ 20040149.pdf).

Scheepers, H., and Scheepers, R. 2004. "The Implementation of Mobile Technology in Organizations: Expanding Individual Use Contexts," in Proceedings of the $25^{\text {th }}$ International Conference on Information Systems, R. Agarwal, L. Kirsch, and J. I. DeGross (eds.), Washington, DC, December 12-15, pp. 171-181.

Sell, A., Patokorpi, E., Walden, P., and Anckar, B. 2004. "Adoption of Mobile Technology: An Empirical Study on Females Working in Elderly Care,"in Proceedings of the $12^{\text {th }}$ European Conference on Information Systems, T. Leino, T. Saarinen, and S. Klein (eds.), Turku, Finland, June 14-16 (http://is2.lse.ac.uk/asp/aspecis/20040154.pdf). 
Seo, M.-G., and Barett, L. F. 2007. "Being Emotional During Decision Making_-Good or Bad? An Empirical Investigation," Academy of Management Journal (50:4), pp. 923-940.

Shapiro, C., and Varian, H. R. 1999. Information Rules: A Strategic Guide to the Network Economy, Boston: Harvard Business School Press.

Stanoevska-Slabeva, K., and Hoegg, R. 2005. "Towards Guidelines for Design of Mobile Services," in Proceedings of the $13^{\text {th }}$ European Conference on Information Systems, Regensburg, Germany, May 26-28.

Szajna, B. 1994. "Software Evaluation and Choice: Predictive Evaluation of the Technology Acceptance Instrument," MIS Quarterly (18:3), pp. 319-324

Thirtle, C. G., and Ruttan, V. W. 1987. The Role of Demand and Supply in the Generation and Diffusion of Technical Change, Chur, Switzerland: Harwood Academic Publishers GmbH.

Tornatzky, L. G., and Klein, K. J. 1982. "Innovation Characteristics and Adoption-Implementation," IEEE Transactions on Engineering Management (EM-29:1), pp. 28-45.

Van der Heijden, H. 2003. "Measuring Attitudes Towards Mobile Information Services: An Empirical Validation of the HED/UT Scale," in Proceedings of the $11^{\text {th }}$ European Conference on Information Systems, Napoli, Italy, June 16-21 (http://is2.lse.ac.uk/asp/aspecis/ 20030166.pdf).

Van der Heijden, H., Ogertschnig, M., and Van der Gaast, L. 2005. "Effects of Context Relevance and Perceived Risk on User Acceptance of Mobile Information Services," in Proceedings of the $13^{\text {th }}$ European Conference on Information Systems, Regensburg, Germany, May 26-28.

Venkatesh, V., and Davis, F. 2007. "A Theoretical Extension of the Technology Acceptance Model: Four Longitudinal Field Studies," Management Science (46:2), pp. 186-204.

Venkatesh, V., Morris, M. G., and Ackerman, P. L. 2000. "A Longitudinal Field Investigation of Gender Differences in Individual Technology Adoption Decision-Making Processes," Organizational Behavior and Human Decision Processes (83:1), pp. 33-60.

Venkatesh, V., Morris, M. G., Davis, G. B., and Davis, F. D. 2003. "User Acceptance of Information Technology: Toward a Unified View," MIS Quarterly (27:3), pp. 425-478.

Wainwright, D. W., and Waring, T. S. 2006. "The Politics of ICT Diffusion: A Case Study in a UK Primary Health Care Trust," in The Transfer and Diffusion of Information Technology for Organizational Resilience, B. Donnellan, T. J. Larsen, L. Levine, and J. I. DeGross (eds), Boston: Springer, pp. 71-90.

Walden, P., Han, S., Carlsson, C., and Majlender, P. 2007. "The Sleeping Giant-A Longitudinal Study Surveying the Mobile Service Market in Finland," in Proceedings of the $15^{\text {th }}$ European Conference on Information Systems, St. Gallen, Switzerland, June 7-9.

Wang, Y., and Yuan, Y. 2006. "The Role of SMS in Mobile Data Service Diffusion in China: A Longitudinal Case Study Based on Actor-Network Theory," in Proceedings of the $27^{\text {th }}$ International Conference on Information Systems, Milwaukee, WI, December 10-13, pp. $1737-1756$.

Wareham, J., Levy, A., and Cousins, K. 2002. "Wireless Diffusion and Mobile Computing: Implications for the Digital Divide," in Proceedings of the $10^{\text {th }}$ European Conference on Information Systems, Gdansk, Poland, June 6-8.

Yoo, Y., Lyytinen, K., and Yang, H. D. 2002. "The Role of Standards in Innovation and Diffusion of Broadband Mobile Services: The Case of South Korea," Journal of Strategic Information Systems (14:3), pp. 323-353.

Zmud, R. W. 1984. "An Examination of Push-Pull Theory Applied to Process Innovation in Knowledge Work," Management Science (30:6), pp. 727-738.

\section{About the Authors}

Heidi Tscherning is a Ph.D. student at the Center for Applied ICT, Copenhagen Business School, Denmark. She holds a Master's degree in Business Administration and Economics from 
the Copenhagen Business School and has seven years of experience in industry working with project management on three IT projects for Danish Defence as well as IT management consulting. Her research is focused on diffusion and adoption of advanced mobile services with a special interest in social networks. Heidi Tscherning can be reached at ht.caict@cbs.dk.

Jan Damsgaard is a professor and the director of Center for Applied Information and Communication Technology at Copenhagen Business School, Denmark. He holds a Master's degree in Computer Science and Psychology and a Ph.D. in Information Systems. His research focuses on the diffusion and implementation of networked and standard-based technologies such as intranets, EDI, and mobile and wireless technologies. He has presented his work at international conferences (ICIS, ECIS, PACIS, HICSS, IFIP 8.2., 8.4, and 8.6) and in international journals (Information Systems Journal, Journal of Strategic Information Systems, Information Society, Information Technology and People, Communications of the ACM, and Journal of the Association for Information Systems). JD has worked and done research at a number of institutions, including Aalborg University, Denmark; Case Western Reserve University, USA; University of Jyväskylä, Finland; University of California at Irvine, USA; and Hong Kong University of Science and Technology, China. JD can be reached at damsgaard@cbs.dk.

\section{Appendix}

This appendix provides an overview of the papers analyzed from the IFIP 8.6, ECIS, and ICIS conference proceedings from 1998 through 2007. The table shows all elements of the framework for each conference contribution. For further information on the papers, see the References.

\begin{tabular}{|c|c|c|c|c|c|c|c|c|c|c|}
\hline ID & Author(s) & 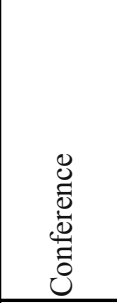 & 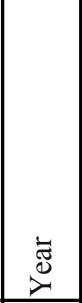 & 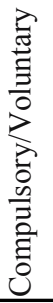 & 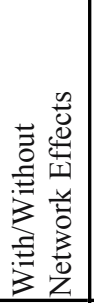 & 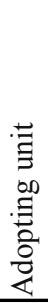 & 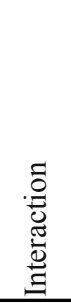 & $\begin{array}{l}\overrightarrow{0} \\
\text { D. } \\
\text { E }\end{array}$ & 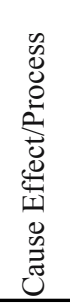 & 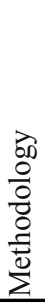 \\
\hline 1 & Lin \& Chiasson & IFIP 8.6 & 2007 & $\mathrm{~V}$ & $\mathrm{w} / \mathrm{o}$ & I & Pull & $\begin{array}{l}\text { DOI, } \\
\text { other }\end{array}$ & C-E & $\mathrm{I}$ \\
\hline 2 & Abu-Samaha \& Mansi & IFIP 8.6 & 2007 & $\mathrm{~V}$ & $\mathrm{w}$ & $\mathrm{I}$ & Pull & None & $\mathrm{C}-\mathrm{E}$ & $\mathrm{P}$ \\
\hline 3 & Wainwright \& Waring & IFIP 8.6 & 1998 & $\mathrm{~V}$ & $\mathrm{w} / \mathrm{o}$ & $\mathrm{O}$ & Pull & DOI & C-E & $\mathrm{I}$ \\
\hline 4 & Ney et al. & IFIP 8.6 & 2004 & $\mathrm{C}$ & $\mathrm{W}$ & $\mathrm{O}$ & Pull & Other & $\mathrm{C}-\mathrm{E}$ & $\mathrm{I}$ \\
\hline 5 & Muzzi \& Kautz & IFIP 8.6 & 2004 & $\mathrm{C}$ & $\mathrm{w} / \mathrm{o}$ & $\mathrm{R}$ & Push & None & $\begin{array}{l}\text { Pro- } \\
\text { cess }\end{array}$ & $\mathrm{I}$ \\
\hline 6 & Hampe \& Schwabe & IFIP 8.6 & 2002 & $\mathrm{~V}$ & $\mathrm{w} / \mathrm{o}$ & $\mathrm{I}$ & Pull & Other & $\mathrm{C}-\mathrm{E}$ & $\mathrm{I}$ \\
\hline 7 & Coursaris et al. & ECIS & 2007 & $\mathrm{~V}$ & $\mathrm{w} / \mathrm{o}$ & $\mathrm{I}$ & Pull & Other & C-E & $\mathrm{P}$ \\
\hline 8 & Knebel et al. & ECIS & 2007 & $\mathrm{~V}$ & $\mathrm{w} / \mathrm{o}$ & $\mathrm{I}$ & Pull & None & C-E & $\mathrm{P}$ \\
\hline 9 & Walden et al. & ECIS & 2007 & $\mathrm{~V}$ & $\mathrm{w} / \mathrm{o}$ & $\mathrm{I}$ & Pull & Other & $\begin{array}{l}\text { Pro- } \\
\text { cess }\end{array}$ & $\mathrm{P}$ \\
\hline 10 & Banderker \& Van Belle & ECIS & 2006 & $\mathrm{C}$ & $\mathrm{W} / \mathrm{o}$ & $\mathrm{O}$ & Pull & TAM & C-E & $\mathrm{I}$ \\
\hline 11 & \begin{tabular}{|l|} 
Constantiou \& \\
Papazafeiropoulou \\
\end{tabular} & ECIS & 2006 & $\mathrm{~V}$ & $\mathrm{~W}$ & $\mathrm{I}$ & Pull & None & C-E & $\mathrm{I}$ \\
\hline 12 & Dwivedi et al. & ECIS & 2006 & $\mathrm{~V}$ & $\mathrm{w} / \mathrm{o}$ & $\mathrm{I}$ & Push & Other & C-E & $\mathrm{P}$ \\
\hline 13 & Breu et al. & ECIS & 2005 & $\mathrm{~V}$ & $\mathrm{~W} / \mathrm{o}$ & $\mathrm{O}$ & Pull & TAM & $\mathrm{C}-\mathrm{E}$ & $\mathrm{I}$ \\
\hline
\end{tabular}




\begin{tabular}{|c|c|c|c|c|c|c|c|c|c|c|}
\hline ID & Author(s) & 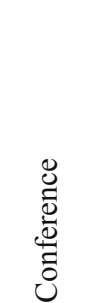 & 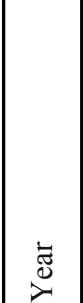 & 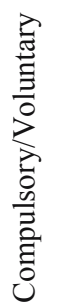 & 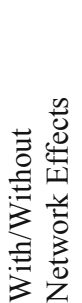 & $\begin{array}{l}. \Xi \\
\Xi \\
00 \\
. \Xi \\
.0 \\
\frac{0}{0} \\
\end{array}$ & 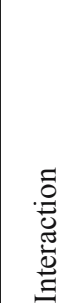 & $\begin{array}{l}\overrightarrow{0} \\
\stackrel{0}{0} \\
E\end{array}$ & 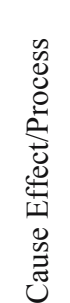 & 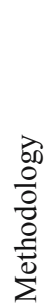 \\
\hline 14 & Carlsson et al. & ECIS & 2005 & $\mathrm{~V}$ & $\mathrm{w} / \mathrm{o}$ & $\mathrm{O}$ & Pull & None & $\mathrm{C}-\mathrm{E}$ & $\mathrm{P}$ \\
\hline 15 & Choudrie and Dwivedi & ECIS & 2005 & $\mathrm{~V}$ & $\mathrm{w} / \mathrm{o}$ & $\mathrm{I}$ & Push & \begin{tabular}{|l|} 
TAM, \\
DOI
\end{tabular} & $\mathrm{C}-\mathrm{E}$ & $\mathrm{P}$ \\
\hline 16 & Constantiou et al. & ECIS & 2005 & $\mathrm{~V}$ & $\mathrm{w} / \mathrm{o}$ & $\mathrm{I}$ & Push & None & $\mathrm{C}-\mathrm{E}$ & $\mathrm{P}$ \\
\hline 17 & Haghirian \& Madlberger & ECIS & 2005 & $\mathrm{~V}$ & $\mathrm{w} / \mathrm{o}$ & $\mathrm{I}$ & Push & Other & $\mathrm{C}-\mathrm{E}$ & $\mathrm{P}$ \\
\hline 18 & $\begin{array}{l}\text { Stanoevska-Slabeva \& } \\
\text { Hoegg }\end{array}$ & ECIS & 2005 & $\mathrm{~V}$ & $\mathrm{w} / \mathrm{o}$ & I & Pull & Other & $\begin{array}{l}\text { Pro- } \\
\text { cess }\end{array}$ & $\mathrm{P}$ \\
\hline 19 & Van der Heijden et al. & ECIS & 2005 & $\mathrm{~V}$ & $\mathrm{w} / \mathrm{o}$ & I & Pull & TAM & C-E & $\mathrm{P}$ \\
\hline 20 & Damsgaard \& Gao & ECIS & 2004 & $\mathrm{~V}$ & $\mathrm{w} / \mathrm{o}$ & $\mathrm{I}$ & Pull & $\begin{array}{l}\text { DOI, } \\
\text { other }\end{array}$ & $\mathrm{C}-\mathrm{E}$ & $\mathrm{I}$ \\
\hline 21 & McManus \& Standing & ECIS & 2004 & $\mathrm{~V}$ & $\mathrm{w} / \mathrm{o}$ & $\mathrm{I}$ & Pull & Other & C-E & $\mathrm{I}$ \\
\hline 22 & Scheepers \& McKay & ECIS & 2004 & $\mathrm{C}$ & $\mathrm{w} / \mathrm{o}$ & $\mathrm{O}$ & Pull & Other & $\begin{array}{l}\text { Pro- } \\
\text { cess }\end{array}$ & $\mathrm{I}$ \\
\hline 23 & Sell et al. & ECIS & 2004 & $\mathrm{C}$ & $\mathrm{w} / \mathrm{o}$ & $\mathrm{O}$ & Pull & TAM & C-E & $\mathrm{P}$ \\
\hline 24 & $\begin{array}{l}\text { Choudrie \& } \\
\text { Papazafeiropoulou }\end{array}$ & ECIS & 2003 & $\mathrm{~V}$ & $\mathrm{w} / \mathrm{o}$ & $\mathrm{O}$ & Pull & Other & $\mathrm{C}-\mathrm{E}$ & $\mathrm{I}$ \\
\hline 25 & Van der Heijden & ECIS & 2003 & $\mathrm{~V}$ & $\mathrm{w} / \mathrm{o}$ & $\mathrm{I}$ & Pull & TAM & C-E & $\mathrm{P}$ \\
\hline 26 & Cheng \& Arthur & ECIS & 2002 & $\mathrm{~V}$ & $\mathrm{w} / \mathrm{o}$ & $\mathrm{I}$ & Pull & Other & C-E & $\mathrm{P}$ \\
\hline 27 & Dahlberg \& Mallat & ECIS & 2002 & $\mathrm{~V}$ & $\mathrm{w} / \mathrm{o}$ & I & Pull & $\begin{array}{l}\text { TAM, } \\
\text { other }\end{array}$ & C-E & I \\
\hline 28 & Leimeister et al. & ECIS & 2002 & $\mathrm{~V}$ & $\mathrm{w} / \mathrm{o}$ & I & Pull & None & C-E & $\mathrm{I}$ \\
\hline 29 & Wareham et al. & ECIS & 2002 & $\mathrm{~V}$ & $\mathrm{w} / \mathrm{o}$ & I & Pull & Other & $\begin{array}{l}\text { Pro- } \\
\text { cess }\end{array}$ & $\mathrm{P}$ \\
\hline 30 & Wang \& Yan & ICIS & 2006 & $\mathrm{~V}$ & $\mathrm{~W}$ & I & Push & Other & $\begin{array}{l}\text { Pro- } \\
\text { cess }\end{array}$ & I \\
\hline 31 & Oh \& Lee & ICIS & 2005 & $\mathrm{~V}$ & $\mathrm{w} / \mathrm{o}$ & $\mathrm{I}$ & Push & Other & C-E & $\mathrm{I}$ \\
\hline 32 & Scheepers \& Scheepers & ICIS & 2004 & $\mathrm{C}$ & $\mathrm{w} / \mathrm{o}$ & $\mathrm{O}$ & Push & Other & $\mathrm{C}-\mathrm{E}$ & $\mathrm{I}$ \\
\hline 33 & Goh et al. & ICIS & 2003 & $\mathrm{~V}$ & $\mathrm{w} / \mathrm{o}$ & I & Push & Other & C-E & $\mathrm{P}$ \\
\hline 34 & Middleton & ICIS & 2002 & $\mathrm{~V}$ & $\overline{\mathrm{W}}$ & $\mathrm{I}$ & Pull & Other & $\mathrm{C}-\mathrm{E}$ & $\mathrm{I}$ \\
\hline 35 & Dutta \& Roy & ICIS & 2001 & $\mathrm{~V}$ & $\mathrm{w} / \mathrm{o}$ & I & Push & Other & C-E & $\mathrm{P}$ \\
\hline 36 & Harrington \& Ruppel & ICIS & 1999 & $\mathrm{C}$ & $\mathrm{W}$ & $\mathrm{G}$ & Push & DOI & $\mathrm{C}-\mathrm{E}$ & $\mathrm{P}$ \\
\hline
\end{tabular}

